\title{
Guest editor's tribute to Friedrich Baucke on the occasion of his 80th birthday
}

\author{
John A. Duffy
}

Received: 5 October 2009 /Accepted: 5 October 2009 /Published online: 20 October 2009

(C) Springer-Verlag 2010

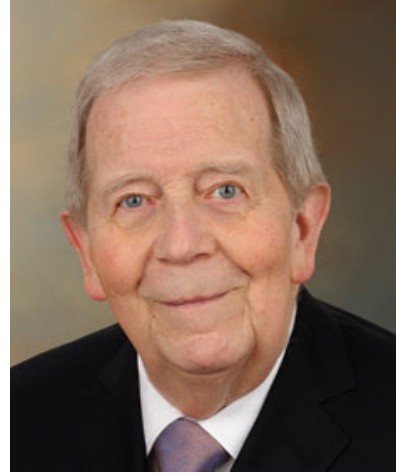

Dr. Friedrich G. K. Baucke, DSc

For many years, Dr. Baucke has been a well-known figure at conferences concerned with the electrochemistry of glasses and related materials. I first met Dr. Baucke in 1972 at a EUCHEM Molten Salts conference in Cirencester, England. We discussed several topics, but mainly the chemistry of glass melts and their acid-base properties, and he suggested that I should visit him at his laboratory at Jenaer Glaswerk Schott und Genossen in Mainz, Germany. This was the start of several visits to Schotts when initially I worked with both Dr. Baucke and his electron microscopist colleague, Dr. H. Bach. These two Schott employees had just been pursuing groundbreaking work, that later established, for the first time, the real mechanism of the glass electrode. The excellent quality of this work was recognised by the American Ceramic Society in conferring on both workers the Morey Award in 1978.

J. A. Duffy $(\bowtie)$

Department of Chemistry, University of Aberdeen,

Old Aberdeen AB24 3UE Scotland, UK

e-mail: j.a.duffy@abdn.ac.uk
Dr. Baucke had joined Schotts in 1968, after returning from the USA, where he had held a post-doctoral fellowship at Berkeley, University of California. Erich Schott, son of Otto Schott (who founded the original Schott company in Jena), required him to establish a research laboratory that would specialise in the electrochemistry of glass, in both the vitreous and the molten state. Naturally, his tasks encompassed a much wider role, and included work on thin films deposited onto glass and also the development of electrochromic devices. During the 1960s and early 1970s, the atmosphere at Schotts encouraged scientists of the calibre of Dr. Baucke to pursue creative ideas in addition to dealing with the more day-to-day problems that arose in the factory. His laboratory, indeed, had an academic atmosphere, although a visitor was always aware that 'both feet were on the ground'.

Some of Dr. Baucke's academic interests overlapped certain areas of my own research (jointly being developed with my colleague, Prof. Malcolm Ingram), and it became appropriate that he should be appointed as an Honorary Visiting Research Fellow in the University of Aberdeen. For more than 20 years, he made regular visits to Aberdeen and it was always a great pleasure when he presented a lecture detailing his latest work at Schotts. He established himself as a popular figure in the Chemistry Department, equally with the staff and research students. During my visits to his laboratory in Mainz, we discussed many ideas. A number of research programmes were devised, such as on the transport of ions through glass and also the redox reactions of metal ion pairs that are important in the manufacture of glass. Work was also undertaken on certain fundamental aspects of electrochromism.

When Dr. Baucke retired from Schotts, he handed over to his successor a first-class laboratory that included a loyal team of well-trained personnel. However, retirement did not 
mean that he entirely disappeared from Schotts. The task was laid before him of reporting in detail the results of all important work that he had undertaken during his time with the company. Schotts had decided that the expertise and findings of their senior scientists should not risk being lost or forgotten, and arrangements were made with SpringerVerlag to publish a number of authoritative text-books on various aspects of glass. The series was edited by his colleagues Prof. D. Krause and Dr. H. Bach, and after several years of careful preparation, Dr. Baucke's book, Electrochemistry of Glasses and Glass Melts, Including Glass Electrodes, was published in 2000. It was immediately recognised as an extremely valuable and exceptional addition to the list of books on glass science. One reviewer described it as 'remarkable' and added that 'there is much to challenge the preconceptions of electrochemists, ceramic engineers, chemists and physicists'.

Dr. Baucke continued as Honorary Visiting Research Fellow at the University of Aberdeen. In due course, special arrangements were made by the University that allowed him to submit appropriate publications for the Doctor of Science degree. The successful outcome resulted in this prestigious degree being conferred in the summer of 2002. The event was seen by his many friends in Aberdeen as a fitting tribute to a scientist whose interests spanned so many aspects of electrochemistry, both academic and the more applied. 